\title{
Asymmetrical Relationship Construction in Medical Interactions - A Case Study of Advice-giving in Mandarin Chinese
}

\author{
Li Chuntao \\ School of Foreign Languages, Shanxi University, Taiyuan, China
}

Email address:

lspring@sxu.edu.cn

To cite this article:

Li Chuntao. Asymmetrical Relationship Construction in Medical Interactions - A Case Study of Advice-giving in Mandarin Chinese. Communication and Linguistics Studies. Vol. 6, No. 1, 2020, pp. 10-15. doi: 10.11648/j.cls.20200601.13

Received: February 20, 2020; Accepted: March 4, 2020; Published: March 17, 2020

\begin{abstract}
Social interactions are fundamental components of social life, and we as social members witness and participate in a myriad of social actions and activities. It is in and through these interactions that cultures are established, identities are constructed and relationships are created, maintained or changed. Conversation analysis (CA), as an emergent discipline and research method, is committed to pin down the refined details in social interaction, in the hope to develop systematic knowledge and analysis of what participants in social interactions do and what they achieve. Doctor-patient interaction has long been a much explored topic in CA, but there is still much to be probed into, as talks in the medical context can be a complicated process dependent on many contingencies arising right from that context. This paper adopts conversation analysis as its research method and takes advice-giving in doctor-patient talks as its focus. It is argued that despite the apparently fixed layman-professional relationship in clinical contexts, the professional and lay people relationship is continually created, maintained and adjusted. In medical contexts, a professional's advice is given with displays of higher epistemic authority, but it may meet with resistances as a result of contingencies in the diagnosis or treatment process. To manage those resistances, a doctor can resort to different practices, including embedding the advice into stories or fusing the advice-giving action into information delivery, and so on. This study aims to contribute to the understanding of dynamic relationship construction and advice-giving practices in medical encounters.
\end{abstract}

Keywords: Advice-giving, Asymmetry, Medical Interaction, Conversation Analysis

\section{Introduction}

Medical interaction is among the most explored institutional talks in conversation analysis (hereafter CA) research. In these interactions, advice-giving is a fundamental action, with a client (a patient) who has a problem and seeks advice in the first place and then a professional (a doctor) who typically has the expertise and mandate to give advice. These interactions are often constructed with normative behaviors but at the same time featured by an asymmetrical relationship construction [1].

Parsons [2, 3] suggests that there exists an asymmetrical relationship between doctor and patient. Doctors deploy specialized resources of knowledge and expertise and provide professionally competent help for patients, by defining the health conditions of a patient and offering technical or psychological help. Heritage and Sefi's paper [4] was among the first fundamental works which defines advice-giving as something which "describes, recommends or otherwise forwards a preferred course of future action" (p. 368), and treats advice-giving as an empirical focus [5]. Building upon their study, there has been substantial CA research which examines advice-giving in other medical contexts such as HIV counselling [6,7], pharmacy interactions $[5,8]$, and health and medical contexts and identifies the particular sequential position and composition features of advice-giving and advice-receiving practices $[9,10]$.

Advice, in the sense that it brings forward to the recipient a "preferred" course of future action, carries at the same time a prescriptive and a moral element $[4,5]$. Advice giving also presupposes and builds up an asymmetry between participants [11], as the advice-giver often displays a higher epistemic stance [12] than the advice recipient. By the very action of 
advice giving, the advice giver offers solutions for a problem, suggesting a course of future action, and thereby displays their epistemic authority.

Meanwhile, the advice recipient may compete for epistemic primacy [13] in terms of their life and experiences, and this may accordingly present to the advice giver implications for when and how advice is delivered. Advice delivery is therefore an interactional achievement for which epistemic asymmetry is negotiated in a moment-by-moment way, not just the basis for advice giving and receipt.

In medical and health-related contexts, a professional's advice is given along with displays of higher epistemic knowledge and authority, and the doctor-patient epistemic asymmetry is made relevant as both reflective and constitutive of the particular medical context [1]. This study just aims to pin down the constitutive mechanism employed by both the doctor and the patient in clinical interactions and hopes to contribute to the understanding and improvement of doctor-patient relationship in general.

\section{Methods}

The data for this study are naturally occurring clinical doctor-patient conversations collected in a third-grade class-A hospital in a northern city of China, and they are included in the CA database of the Discourse and Interaction Group (DIG), Shanxi University, PR China. There are currently eight clinical diagnoses audio or video interactions involved, and the total length is more than one hour. The transcription followed the CA conventions developed by Gail Jefferson [14] and adjusted for showing Mandarin data. There are three lines for each turn, the first is transcription in pinyin Mandarin, the second line is literal translation in English, and then in the third part a more idiomatic form of English translation is provided.

From a CA perspective, the interactional order is jointly constructed and develops incrementally with the participants collaboratively create, maintain and promote the conversation in a moment-by-moment way [15]. During that process, participants orient to the ongoing conversational task and their co-participant as well, so the interaction is always reflexive and characteristic of recipient-design [16, 17]. Institutional talks, in particular, are task-oriented and are usually defined and constrained by the working context. Naturally, participants' identities or category memberships $[18,19]$ are made relevant or consequential in that context. On the other hand, institutional talks are also interactional achievements accomplished through the constitutive efforts of the interactional participants during the interactional process [20]. Doctor-patient relationship, with regard to their respective identity construction, is rightly among these co-constructed products.

\section{Discussion}

\subsection{The Epistemic Perspective: Doctor Authority and Other-attentiveness}

In doctor-patient interactions, there seems inherently an asymmetrical epistemic contrast. It is important to notice, from a CA perspective, that this contrastive relationship is momentarily created, maintained, challenged and negotiated. A doctor is supposed to assume an institutional role of authority and expertise, but this role is not one that is taken for granted. Instead, it is constantly built up with the doctor's displays of $\mathrm{k}+$ stance, and this epistemically $\mathrm{k}+$ stance may manifest in three aspects:

1) Knowledge in medicinal diagnosis and care;

2) Other-attentiveness toward the patient;

3) Knowledge of the interactional context around which doctor-patient interaction goes on.

Take Excerpt 1 as an example. This excerpt is drawn from a video-recorded naturally occurring conversation between a doctor and a patient's daughter who came to the hospital in place of the patient (her father) who "is rather old and has bronchitis" and so for whom coming to the hospital in person is difficult.

Excerpt 1 (Urine burning pain)

44. D: zhègè: dāngshí yǒu gănrăn,

This then have infection

zuò guò niào- (niào piàn) ma,

do CRS urine urine piece PRT

There was infection here at that time. Have you ever done uroscopy?

45. P: e zuò lái, shì yǒu-

Uhm do CRS yes have

wǒ juédé tā xiànzài zhègè zhèngzhuàng

I feel it now this symptom

hăoxiàng shì hé tā yuánlái

seem be with it before

nàgè zhèngzhuàng yǒudiăn xiàng $(0.2)$ hā,

that symptom a little similar PRT

Uhm, He has done one. Yes, there is- I think that now the symptom seems to be like that of the past.

46. D: xiànzài niào xuè bú niào le.

Now urinate blood no urinate PRT

Now is there still blood in your urine or not?

47. $\mathrm{P}$ : bú niào, jiù nà yî̀ì, jiù nà yî tiān nà yî̀i $\overline{\mathrm{o}}: \overline{\mathrm{o}}$

No urinate just that once just that one day that once oh oh

No, no longer. Just once on that day.

48. D: nǐzhè yào chá niào sān bēi le,

You this need check urine three glass PRT

jiù shì yào chá gănrăn de wèntí.

Just be need check infection NOM problem

You now need to take a urine three-glass test, that is, you need to check the problem of infection.

49. $P$ : chá gănrăn de wèntí le hā,

Check infection NOM problem PRT PRT

I need to check the problem of infection, right?

50. D: duì.

Right.

Right.

It can be seen from the excerpt that after history-taking, the doctor begins to give diagnosis advice. We may look at turn 48 . yao in Mandarin Chinese means "will have to", and the doctor designs his turn with an affirmative statement, telling the 
patient's daughter what test is needed before the diagnosis. And after the technical term niaosanbei ("urine three-glass test"), the doctor reformulates it, with a reformulation marker jiushi ("that is"). But in this reformulation, the doctor does not explain what the three glasses refer to, which might entail more technical terms that are potentially beyond the recipient's epistemic scope. Instead, he gives an account for the proposed action, that is, to examine the problem of infection (ganran wenti). The reformulation is framed by the repeated modal verb yao, which semantically links the reformulation part to what is reformulated in the former part of the turn.

Paraphrastic reformulation [21] is a common kind of reformulation that uses a specific marker (yao in this case) or a fixed expression which can explicitly form a connected equivalence. And the equivalence may be imposed by these semantic markers or expressions regardless of the content of the source segment (S) and the reformulated segment (R) [22]. When the speaker readjusts his turn with these markers or expressions, they often serve to suggest a better formulation than $\mathrm{S}$, in which sense they may well represent a turn design that is more accurate, more appropriate or more epistemically understandably or acceptable to the recipient. To put it another way, the reformulation itself displays other-attentiveness in that the very production of it is a result of the recipient design $[16,17]$ of the speaker.

With this reformulation turn, the doctor displays his:

1) Epistemic primacy as a normatively recognized authority in the test in question;

2) Epistemically higher gradient relative to the patient's Kepistemic status;

3) Attentiveness to the patient's presumable lack of professional knowledge;

4) Recipient design with orientation to the patient's epistemically K- status.

It can be further observed that with this reformulation, the advice-giving sequence can be much more efficient in that at this moment of diagnosis, when the test is just advised rather than decided on, details are not yet necessary. The technical term, although it displays the doctor' epistemic primacy, may be difficult or even incomprehensible to the patient. That's why after the technical term, the doctor follows with this reformulation that shows the doctor's attentiveness to the patient. By pointing out the purpose of the test, the doctor designs his turn as sufficient for the patient to understand the core of the advice. All these practices are in fact the manifestations of the doctor's medical expertise, which include not only medical knowledge, but also understandings of the patient and the patient's epistemic stance, and the considerations of diagnosis effectiveness and efficiency.

\subsection{Contestive Epistemic Stances: Negotiation and Resistance}

After the doctor's advice-giving turn, in turn 49, the patient's daughter responds with a partial repeat of the doctor's turn, and the repeated part is only the reformulated version instead of the whole turn. With this repeat, we can make the following observations:

1) The patient respects the doctor's epistemic authority;

2) The patient uses the repeat to confirm the receipt of the advice;

3) The patient displays her now-understanding epistemic stance;

4) The patient recognizes the value of the advice;

5) The patient accepts the advice as she repeats it to (possibly) memorize.

In turn 49, the patient initiates a repair [23], with a partial repeat of the doctor's utterance in turn 48 , plus a turn final particle $h a$. From the patient's partial repeat, we can observe that what she repeats is the reformulated part of the turn instead of the part of the technical term. This may well serve as evidence for the presumption that the doctor has oriented to when he self-corrects in turn 48 . For the present moment, the relatively everyday wording of "problem of infection" is obviously adequate for the patient, as she does not repeat that "urine three-glass test" part, nor does she display any interest, curiosity or doubt whatsoever. And the turn final particle $h a$ is a typical question marker of seeking confirmation, which makes the doctor's response relevant. With this particle, the patient is further ceding the epistemic right to the doctor, acknowledging him as the authoritative source of information.

The doctor's status of authority or expertise, however, can be vulnerable to challenges or doubts from the patient or the third party, very often a family member of the patient. And the action of advice-giving can often meet with resistance or suspicion as well. We can see in turn 50 that the doctor's third turn response dui ("right") confirms the patient's receipt of information and at the same time claims his epistemic primacy. But then the doctor's advice is met with resistance in turn 51:

Excerpt 2 (Urine burning pain)

51. P: kěshì yīnwéi tā niánlíng dà le,

But because he age big PRT

ránhòu yīzhí hái yǒu zhègè (.) zhīqìguănyán,

Then always still have this bronchitis

But because he is old, and he has always had bronchitis.

52. D: $\overline{0}:$ :

$\mathrm{Oh}$

Oh.

53. $\mathrm{P}$ : ránhòu jiùshì ȳ̄ jiàn fēng:: ránhòu jiù késòu,

Then just once see wind then just cough

jiù kě duō nián le,

Just quite many year PRT

jīnnián háishì hăo yīdiăn,

This year nevertheless good a little

So once he is outdoors and meets with wind, he will just cough. although these years he has improved a little.

54. $P$ : jiù yī- yî rù dōng jiù- jǐhū jiù

Just once once enter winter just almost just

méi ràng zěnme chū guò mén

not let somehow out PRT door

jiùshì nàcì kànbìng de shíhòu lái zhè,

Just that time see the doctor NOM time come here ránhòu lái dāi le jǐtiān. 
Then come stay PRT several days.

Once winter is coming, he is almost never allowed to go out. The only exception was last time when we came here to see the doctor. That time he stayed in hospital for several days.

(8s) ((The doctor did the record work on the computer.))

55. $\mathrm{P}$ : fãnzhèng tā qiánlièxiàn hăoxiàng háishì tǐng $(0.2)$ tǐng dàde hā,

Anyway he prostate seem still quite quite big PRT

Anyway his prostate still seems quite big, right?

56. D: èn:

EXL

Yes.

57. P: [fãnzhèng tā bú -

Anyway he not

Anyway he is not......

After the doctor's confirmation, the patient initiates her turn in turn 51 with keshi ("but"), which may well project resistance to the advice. The doctor's advice clearly entails the prerequisite for the urine test: The patient has to come to the hospital in person. Given that, the patient's daughter resists the advice with several accounts:

1) The patient's old age ("because he is old" in turn 51), which is a factual constraint that limits the patient's physical ability to come to the hospital.

2) The patient's relevant disease, bronchitis, which is also a practical constraint that constitutes the resistance to the doctor's urine test advice.

3) The patient's specific symptoms as a result of the first two factors.

In these accounts, the patient's daughter repeatedly uses extreme case formulations (ECF) [24] to highlight the patient's troubles that inhibit his coming to the hospital, such as yizhi haiyou zhege zhiqiguanyan ("he has always had bronchitis"), yi jianfeng ranhou jiu kesou ("once he is outdoors and meets with wind, he will just cough"), keduonian le ("quite many years"), yirudong jiu jihu jiu mei rang zenme chuguomen ("Once winter is coming, he is almost never allowed to go out."). All these serve to highlight the contingencies that the patient may have if committing to the preferred future action as suggested by the doctor.

From the observations, we find that resistance from the patient's side comes more from practical limitations of capabilities rather than personal unwillingness or denial of the doctor's diagnosis as unhelpful. The accounts occupy more than one turn constructional unit (TCU), in contrast to the doctor's minimal response in turn 52, ao ("oh"), a change-of-state token [25] acknowledging his knowing of the patient's difficulties in coming in to take the test in person. With no further response from the doctor, the patient's daughter goes on to elaborate on the specific symptoms and experiences of the patient. And the specified description further makes clear the patient's difficulty, and the daughter has used a turn design of "he is almost never allowed to go out". This passive construction again pushes the patient away from becoming the one who is potentially taking up the responsibility of not taking the test (and maybe then the follow-up treatment), and the caregivers would take the blame.
This is more or less a morality issue. The caregivers are shouldering responsibilities, and out of considerations of the patient's health, they do not allow him to go out (but not the patient himself is unwilling or probably unable to), lest he should cough.

After the daughter's complaint, there is a rather long silence of 8 seconds, which is far longer than a normal inter-turn silence of $1 / 20$ second. During the extraordinarily long silence, the doctor is ostensibly doing computer filing work, without contributing more to the ongoing process of diagnosis. This may suggest a certain delicacy in tackling the dilemma. Toerien and Jackson [26] note that disagreement often happens with conflicts kept "beneath the surface" of interaction, "present but unsaid" (p. 38). Shaw et al [27] suggests that when giving advice, a doctor often has to accommodate the many possible contingencies, and it can be very possible that the very action of advice giving can be negatively affected.

\section{Conclusion}

Heritage and Sefi [4] note that advice giving is both normative and asymmetric. It is normatively prescriptive because it suggests what should be done in the future on the grounds that the future action is necessary or beneficial for the advice recipient. On the other hand, advice giving also implies asymmetry, at least epistemically, as the advice giver is supposed to be more knowledgeable, having more professional expertise or more life experiences than the advice recipient.

Despite the presupposed normativity and epistemic asymmetry, advice may still meet with resistance. In medical encounters, patients may have experienced many diagnoses or treatment recommendations. It is quite common that patients or their caregivers do not register the advice as news. That is, the patients may have had prior and maybe similar knowledge of the diagnosis or the treatment. In their responses to the doctor's advice, there can be no sign to show that they are going to act on that advice.

Besides knowledge about the diagnosis, the patient may also contest for epistemic independence in light of their own life experiences, living environments, treatment affordability, etc. From the above observed Excerpt 2, we can easily see that the patient is indeed having difficulties to follow the doctor's test recommendation, due to practical constraints of his physical conditions, to which the doctor may lack access of knowledge until the caregiver provides. But it is worthwhile to note that patient resistance can often come in an indirect way [28], possibly from the influence of a stereotyped doctor-patient relationship where the doctor's status of professional authority is appreciated.

Silverman [7] points out that advice can meet with resistances in different contexts. When proposing treatement, the doctor's different turn designs, e.g. lexical choices or semantic options, may also be observably consequential [29]. To manage those resistances, some effective ways can include embedding the advice into stories or downgrading the 
asymmetrical presupposition by fusing the advice-giving action into information delivery. There are certainly other practices that can be utilized to manage resistance to advice-giving, and studies on this topic are specifically meaningful in institutional talks like medical encounters. What diagnosis or treatment recommendation can be appropriate and healthy for the patient, and how that recommendation can be effectively delivered, all these can contribute to the better understanding of the doctor-patient interactions. Still, further empirical investigations are needed to really grasp the momentary developmental details and their interactional import in the medical encounters [30]. Future research is needed as to how medical institutions can better accommodate patients' concerns and troubles, and how doctors as medical professionals can manage patients' resistance in a more personalized way.

\section{Acknowledgements}

This article is funded by the program of Youth Fund for Humanities and Social Sciences Research, Ministry of Education titled "A Conversation Analytic Study of Question-Response Sequence in Mandarin Chinese" (18YJCZH075).

\section{References}

[1] C. W. Butler, J. Potter, S. Danby, M. Emmison, and A. Hepburn, (2010). Advice-implicative interrogatives. Social Psychology Quarterly 73 (3), 265-287.

[2] T. Parsons, The Social System. New York: The Free Press, 1951.

[3] T. Parsons, (1975). The sick role and the role of the physician reconsidered. Milbank Memorial Fund Quarterly, 53: 257-78.

[4] J. Heritage, and S. Sefi, "Dilemmas of advice: Aspects of the delivery and reception of advice in interactions between health visitors and first time mothers", In Talk at Work: Interaction in Institutional Settings, P. Drew and J. Heritage, Eds. Cambridge: Cambridge University Press, 1992, pp. 359-419.

[5] A. Pilnick, (1999). "Patient counseling" by pharmacists: Advice, information, or instruction? Sociological Quarterly 40 (4): 613-622.

[6] A. Kinnell, and D. Maynard, (1996). The delivery and receipt of safer sex advice in pre-test counseling sessions for HIV and AIDS. Journal of Contemporary Ethnography 35: 405-437.

[7] D. Silverman, Discourses of Counselling: HIV Counselling as Social Interaction. London, England: Sage, 1997.

[8] A. Pilnick, and T. Coleman, (2003). "I'll give up smoking when you get me better": patients' resistance to attempts to problematise smoking in general practice (GP) consultations. Social Science and Medicine 57 (1): 135-145.

[9] C. W. Butler, S. Danby, M. Emmison, and K. Thorpe, (2009). Managing medical advice seeking in calls to Child Health Line. Sociology of Health and Illness 31 (6): 817-834.

[10] A. Hepburn, and J. Potter, (2011). Designing the recipient:
Managing advice resistance in institutional settings. Social Psychology Quarterly 74 (2), 216-241.

[11] I. Hutchby, (1995). Aspects of recipient design in expert advice-giving on call-in radio. Discourse Processes 19 (2): 219-238.

[12] J. Heritage, "Epistemics in conversation", in The Handbook of Conversation Analysis, J. Sidnell and T. Stivers, Eds. Chichester: Wiley-Blackwell, 2013, pp. 370-394.

[13] J. Heritage, and G. Raymond, (2005). The terms of agreement: Indexing epistemic authority and subordination in talk-in-interaction. Social Psychology Quarterly 68: 15-38.

[14] G. Jefferson, "A glossary of transcript symbols with an introduction", in Conversation Analysis: Studies from the First Generation, G. Lerner, Ed., Amsterdam: John Benjamins, 2004, pp. 13-31.

[15] L. Mondada, "The conversation analytic approach to data collection", in The Handbook of Conversation Analysis, J. Sidnell and T. Stivers, Eds. Chichester: Wiley-Blackwell, 2013, pp. 32-56.

[16] P. Drew, "Turn design", in The Handbook of Conversation Analysis, J. Sidnell and T. Stivers, Eds. Chichester: Wiley-Blackwell, 2013, pp. 131-149.

[17] H. Sacks, E. A. Schegloff, and G. Jefferson, (1974). A simplest systematics for the organization of turn-taking in conversation. Language 50: 696-735.

[18] H. Sacks, Lectures on Conversation. Oxford: Blackwell, 1992.

[19] E. A. Schegloff, (2007). Tutorial on membership categorization. Journal of Pragmatics 39: 462-482.

[20] J. Heritage, and S. Clayman, Talk in Action: Interactions, Identities and Institutions. Oxford: Wiley - Blackwell, 2010.

[21] E. Gülich, and T. Kotschi, "Les actes de reformulation dans la consultation La dame de Caluire, in L'analyse des interactions verbales. La dame de Caluire: une consultation, P. Bange, Ed. P Lang, Berne, 1987, pp. 15-81.

[22] B. Pennec, Discourse Readjustment (s) in Contemporary English. John Wiley \& Sons, Inc., 2018, pp. 75-87.

[23] C. Kitzinger, (2013). "Repair", in The Handbook of Conversation Analysis, J. Sidnell and T. Stivers, Eds. Chichester: Wiley-Blackwell, 2013, pp. 229-256.

[24] A. Pomrantz, (1986). Extreme case formulations: A way of legitimizing claims. Human Studies 9: 219-226.

[25] J. Heritage, "A change-of-state token and aspects of its sequential placement", in Structures of Social Action: Studies in Conversation Analysis, J. M. Atkinson and J. Heritage, Eds. Cambridge: Cambridge University Press, 1984, pp. 299-345.

[26] M. Toerien, and C. Jackson, "Seeing silenced agendas in medical interaction: A conversation analytic case study", in Qualitative Studies of Silence: The Unsaid as Social Action, A. Murray and K. Durrheim, Eds. Cambridge: Cambridge University Press, 2019, pp. 38-58.

[27] C. Shaw, J. Potter, and A. Hepburn, (2015). Advice-implicative actions: Using interrogatives and assessments to deliver advice in mundane conversation. Discourse Studies 17: 317-342. 
[28] L. Wu, (2017). Symptom assessment and patient resistance in primary care interactions in Chinese hospitals. East Asian Pragmatics, 2 (2): 259-288.

[29] S. Kushida and Y. Yamakawa, (2015). Fitting proposals to their sequential environment: A comparison of turn designs for proposing treatment in ongoing outpatient psychiatric consultations in Japan. Sociology of Health \& Illness 37 (4), $522-544$.

[30] J. Heritage and A. McArthur, (2019). The diagnostic moment: A study in US primary care, Social Science \& Medicine, 228: 262-271. 